\title{
1. Introduction to sukuk Islamic debt securities markets
}

\author{
Mohamed Ariff, Munawar Iqbal and \\ Shamsher Mohamad
}

\subsection{INTRODUCTION TO THE BOOK ON SUKUK SECURITIES}

This book is the outcome of a joint effort of a number of senior practising professionals as well as leading research scholars and educators in Islamic finance. The result is a reliable book on the subject of sukuk securities. Though this type of security is new to modern Islamic finance, it has its historical roots some centuries earlier as a novel instrument developed in the Turkish Empire based on earlier practices of government treasuries to raise money. Sukuk securities were first offered just about 20 years ago as part of a slew of new Islamic financial products to fund activities mostly over a finite horizon, since these are financing contracts priced not by using interest rates but by using returns on profit sharing-based contracts and asset-backing for the finance provided.

This is noteworthy since Islamic banking, a financial intermediation paradigm designed to use profit sharing, has taken some 50 years to establish credibility as a new model that is not only viable, but that also has many additional benefits. Accordingly, it has spread across the world. One of the differences between Islamic and conventional finance is that the pricing of Islamic financial products is based on sharing a portion of profits/returns (or as a secured fee) only after profit is earned: the only exception is in a particular product where no reward is to be asked from the borrower, unless voluntarily given. Hence a fund provider actually participates in the risk of funding an economic activity before getting a reward for financing. Islamic finance treats reward and entrepreneurship as a conjoint matter so no reward can be had unless the contract specifies a profit (or secured fee) that could be earned by the borrower ex post.

This contrasts with conventional modern funding arrangements, where investors secure a return based on pre-agreed rewards based on interest 
rates (which are externally determined and not related to profits to the entrepreneur from the use of funds) with no provision to participate in the risk of the economic activity to which the fund is applied. This essential aspect is common in all Islamic funding arrangements. To that key difference, we can add several ethical no-go zones such as restricting funding to only socially-conducive economic activities (no funds for operating a casino, for example). Relevant for the sukuk securities is the requirement that fund seekers will not be able to obtain financing if they have no assets to back funds raised. These and other principles form the foundations of Islamic finance. These are explained in this book in some detail. The focus of the book is also on how the sukuk securities industry functions in terms of institutional organization, rules, and operations of the market players.

There exists today a voluminous body of literature on several aspects of Islamic finance on the interpretation and applications of the basic shari'ah principles (Islamic common law principles) relating to investment, financing economic production and the modes of financial transactions as well as contractual matters. It must be mentioned though that many of the available publications in that large body of literature already available are products of serious rigorous research. There are also publications that promote the agenda of the sponsors of a particular researcher with scant reference to modern finance in general or even how Islamic finance ought to be grounded in the same processes applied in the mother discipline of financial economics.

A more concerting issue in the literature is the current trend of criticizing Islamic finance and the widespread view among many that the success of Islamic finance depends on how well it can replicate conventional finance! Islamic finance can learn from conventional financial contracts, and vice versa, but there is absolutely no need for Islamic finance to mimic every conventional contract or its conditions. That is one of the contributions of Islamic finance. The consumer has a wider choice-set, since the two models have a different modus operandi. If one understands that the pricing of financial products in Islamic finance is based on different principles, namely profit-and-risk sharing or fee-based charges, then one's understanding of how these pricing mechanisms could lead to market clearing prices that are socially welfare-promoting is easy to understand. This book is not a panacea for all issues mentioned but it adopts the classic method of modern inquiry in economics, deliberates the research outputs with peers qualified to do so, and then produces an authentic literature on a current hot topic in finance, the so-called Islamic bonds - namely the markets for sukuk certificates.

Hence, this book should enable one to have a clear understanding of what sukuk securities (so-called Islamic bonds) are, how these are 
designed, traded, how the securities provide incomes via profit share (and mark-up fee) to investors and how these are redeemed at maturity. The one important thing, hitherto not widely addressed in sukuk literature, is the inclusion of several chapters meant to elucidate concept development, state theory-type discussions and attempt some valuation principles based on sound modern financial techniques common in financial economics. It may not be an overstatement to suggest here that there has been a rush to make viable markets for this new type security in about 12 international locations, of which Kuala Lumpur in Malaysia has become the leader, with Bahrain and UAE following closely. ${ }^{1}$ The result is that little attention has been given to the concept development and elucidation needed to understand this security type as a different class of instruments. Another deficiency in the literature is that little attention has been given to developing basic valuation equations for sukuk securities.

This situation is very serious because market participants assume that the revelation of market price in the process of buying and selling a sukuk instrument is the true indication of the theoretical value of this new type of security in Islamic finance. Needless to say, this is not the case. Continued absence of sound valuation theories is likely to retard the growth of the industry since investors and analysts also need valid pricing models to establish fair prices, in addition to the ubiquitous market price. The intrinsic values of conventional securities have been established over several decades of concept development over time, resulting in basic valuation models to guide practices and education.

We believe that this modest effort of ours is welcomed by (i) the industry and (ii) scholars as likely to lead the inquiry in due time to valid conceptual and valuation models. In the case of some types of sukuk securities that could not be traded in public markets, there are no market prices for them. Notional values have to be calculated, and this also requires valuation models.

\subsection{STRUCTURE OF THE BOOK}

To provide a sound introduction to achieve both concept development and to describe practice issues, this book is divided into three parts. In Part I the reader will find concept development and valuation issues that lay what we believe are the foundation principles of sukuk securities. Sukuk markets that operate in more than a dozen different locations in SouthEast Asia and the Middle East (as well as other locations) are regulated by authorities with special laws and regulations geared to orderly market development and price discovery. Because of limitation of space, we only 
cover the regulatory framework in Bahrain, UAE and Malaysia as examples of the regimes in other locations. This aspect is covered in Part II under the heading of regulations and governance.

Part III is intended as an introduction to the practices of the market place. There is a vast body of literature on this aspect; in fact this has been the dominant theme of most of the books and articles that appear in the press and are held in the libraries as well as found as non-reviewed materials in Internet sources. We made a judicious choice of only selecting the common themes under this topic. We cover the widespread practice of marking-to-market as the traded fair value of sukuk securities to provide a guide to the investors. We have a chapter on origination of sukuk securities from the design to marketing and listing for trade. This part also includes a chapter that highlights a number of unresolved issues undergoing discussions with a view to removing obstacles to the orderly development of the market.

\subsection{CONTRIBUTIONS OF THE BOOK}

Concept development is attempted in a chapter by Mohamed Ariff, Meysam Safari and Shamsher Mohamed. The central theme covered is the description of the fundamentals of sukuk securities as Islamic financial instruments for funding economic activities (i) via profit-sharing after income is earned through (ii) risk-sharing with the entrepreneur who raises funds using sukuk. An attempt is made to provide a valid classification of the wide-ranging sukuk securities so writers may focus on the basic types and the basic types could lend themselves to ease of modelling and valuation. The cash flow patterns are established before the fundamental principles are laid that should guide the development of valuation models, in so doing, broadly following the rigour of modern finance. There is an attempt to establish some valuation models to be tested in the market in subsequent research. Thus, this contribution establishes the link between fundamentals and theoretical valuation modelling.

In the next chapter written by Abdullah Saeed and Omar Salah, the reader will find a judicious treatment of how avoidance of usury and the meaning of interest rate are two relevant fundamental principles in the design and trading of sukuk securities. The authors are careful to explain how the contemporary narrow interpretation of avoidance of interest is a development over just about 100 years, which has equated interest with usury as the widely accepted idea in Islamic finance today. Historical evidence suggests that this contemporary modern concept is a recent development as a consensus building exercise to face the reality of 
modern banking and financial practices. This is a theory-relevant chapter for the readers, and the writers ably discuss and clarify the jurisprudential issues relating to interest and usury.

Munawar Iqbal gives coherence to the fundamental principles that should guide the design of sukuk (indeed any other) financial products in line with a set of what he calls ten financial engineering principles. The debate here is to build a theory to represent the core requirements in Islamic finance to guide professionals to design shari'ah-consistent sukuk and other financial products. This chapter is a crucial framework for the design of products while it also serves as a theoretical summary of the principles guiding Islamic finance. This chapter is an essential read for all practitioners as it marks the perimeters within which securities ought to be designed to be in line with fundamental principles of Islamic economics and finance.

The last chapter in this part is a contribution by Murat Çizakça, an economic historian, who traces how the concept of gharar (uncertainty) was handled in public finance sukuk practices in the Turkish Empire. The topic of Islamic public finance is a larger area, which is not covered in this chapter, yet the author gives archive-based evidence to show how public finance techniques underwent a new interpretation and yet are consistent with shari'ah laws applied to changing circumstances. His archival-based research paper is a very welcome addition that pinpoints the origin of sukuk as being traced to an era when modern banking did not exist, and that funding arrangements akin to today's sukuk were in vogue in an earlier era. Sukuk provided the massive funding for infrastructure projects in that empire after the devastations from crusades over two centuries of warfare. His discussion also includes how the concept of risk as it was known then crept into the Western literature as a useful concept in economics at that time. The role of sukuk in public finance needs a separate research effort: this is particularly important since sovereign sukuk issues are about a third to half of the market issues.

Part II has three chapters on regulation and governance issues. All sukuk markets are carefully regulated by authorities responsible for deposittaking firms and for securities trading. Hence, this aspect of regulations and the extent to which regulations are complied with by industry players answers the governance issues in this field. The first chapter describes the regulatory framework in Dubai, contributed by the chief regulator there, Peter Casey. His attempt to treat sukuk instruments as debt instruments is a simple way to get at the heart of this market for regulatory purposes. He describes the framework of such regulations, which is somewhat common in Abu Dhabi and Sharjah in the United Arab Emirates. 
Bahrain has a different approach to regulations and this is described by Sat Paul Parashar to highlight the important aspects that guide this second largest important market. Michael T. Skully examines the sukuk securitization process as a special case of securitization in general. His attempt is interesting in that the differences are highlighted just to reveal that the principles applied under a set of general principles are workable.

In Part III, the contributors are concerned about practices, a major issue addressed in this book. This is attempted very ably by Nassar H. Saidi, a practising economist, who lays out the fundamental facts about sukuk markets. His take in his chapter is to highlight where the market is around the world as at 2010, what impediments to growth are and what actions are needed to grow the sukuk markets around the world. His helicopter view provides a broad-based introduction to practices before he goes on to indicate the strategy needed to achieve this growth.

The growth of the sukuk market in Bahrain is described by Sat Paul Parashar. His extensive analysis with statistics provides a simplified description of the growing complexity of this very new market, which is the second largest among the twelve in Islamic finance. Two practitioners (Meor Amri Ayob and Shamsun Anwar Hussein) respectively provide descriptions on how sukuk securities are priced with reference to market prices and how sukuk are originated and sold.

It is evident that there are significant differences in the manner in which a sukuk is designed as a consequence of the fundamental principles of Islamic finance that must be adhered to. Beyond that, there are important issues regarding how a Special Purpose Company (SPC) takes over some income-producing assets of a borrower to enable sukuk holders to have real claims on assets removed from the control of the borrower. This is a fundamental difference in sukuk to (i) only provide funding if there are income-producing assets (or a known value of such future assets could exist in the case of working capital finance) that could be immediately owned by the financer and (ii) limit the appetite for unwarranted leverage. This fundamental provision in Islamic financial contracts - we call this the principle of 'no assets no funds' - limits the ability of governments, firms and individuals to raise too much funding, which cannot be serviced later (a major cause of recurrent financial crises and hence this automatic break is another major contribution as a society-wide benefit of Islamic finance). The aspect of heavy leveraging by economic agents has been hotly debated since the 2007-2008 Global Financial Crisis (GFC) exposed the weaknesses of firms and especially of governments with huge debt overhang. This bad universal practice is one that the world has to grapple with in the near term to prevent a recurrence of the credit-explosion-led crises during 
the last half of the twentieth century as well as the opening crisis of this century at the time of the GFC and after.

Salman Syed Ali Khan's chapter is aimed at how the Islamic Development Bank (IDB) is helping to develop this new niche finance across its constituent countries, some 56 nations, by practising finance consistent with Islamic financial principles. This is an important chapter, which suggests that international institutions with such august aims as eradicating poverty (World Bank) should perhaps turnover a new leaf in the light of how this is ably done by the IDB using contracts based on profit sharing or fee-based charges instead of interest rates. IDB's major contribution is in trade financing using Islamic principles: about twothirds of its activities are in that area. The last chapter is about unresolved concerns that require the urgent attention of theoreticians, practitioners and regulators if the development of this new niche debt market is to be furthered. It is evident that this new financial market has features that appear to moderate the appetite for debt, actual returns being conditional on profit-making and of course risk being shared, among others.

\subsection{COMMENT}

We firmly believe that there are many aspects of sukuk markets that could be covered in more than one book such as this. We have indicated the need to examine public finance ${ }^{2}$ and to that we can add more topics, including a topic on measuring the risk of sukuk from the angle of asset transfer to sukuk holders via the SPC or from the angle of earnings volatility. However, this book has aspects of coverage that we term theoretical and fundamental in nature, more so than is found in many books. This contribution, we hope, will be appreciated by regulators, educators and professionals as reference book to assist them in their job of running the markets and for the serious students of Islamic finance to help them in their understanding of this market. More technical aspects need further research.

\section{NOTES}

1. Hong Kong, in line with its reputation as an international financial market, has lined up its first sukuk issue for 2011 using Chinese Yuan, while Seoul in Korea, Egypt, and several other locations are making an effort to create sukuk markets.

2. The editors are grateful to the anonymous reviewer of the manuscript for this comment. We agree that the historical use of the sukuk instrument to finance public expenditure is a topic that needs to be carefully verified. In addition, this instrument provides an 
automatic break for too much debt issue by an issuer, because unfettered issue of debt by sovereigns cannot be made because holders of this form of securities require assets of the government to be set aside in SPCs as required by the shari'ah principle. In a sense, a firm issuing too much debt would have very little of its assets since each time an issue is made, the assets under the control of the firm will shrink. 